\title{
INTERPRETATION OF DABA SCRIPT: GEMU FROM WUJIAO ViLLAGE
}

\section{XU Duoduo}

Nanyang Technological University, Singapore

duoduo001@e.ntu.edu.sg

\begin{abstract}
Daba calendars are the only written texts of Dabaism discovered so far. Some studies have been discontinuously conducted on this topic since the first report on this script in 1940. However, some unclear and obscure hermeneutic points of Daba script have still to be investigated in-depth. In this paper, I present an interpretation of one of the Daba calendars based on my original field work data. This Daba calendar, entitled "Gemu", origins in Wūjiǎo (屋脚) village. It is relatively old and, compared to others, shows an archaic version of the Daba calendars, according to the classification proposed in Song (2003). The present study aims to expand our knowledge of the Daba script and of the context in which it was and is still used. Further on, this paper can contribute to establishing a philological foundation for further research on the Daba script, and related comparative studies.
\end{abstract}

Keywords: Daba Script; Gemu; Wujiao Village; Lunar Mansion; Script Interpretation

\section{Povzetek}

Koledarji Daba so edina znana pisna besedila dabaizma. Od prvega poročila iz leta 1940 do danes je nastalo nekaj nepovezanih študij, ki niso povsem odgovorile na nekatera hermenevtična vprašanja v zvezi s pisavo Daba. Članek podaja razlago enega izmed koledarjev Daba in temelji na izsledkih terenske raziskave. Obravnavani koledar se imenuje "Gemu" in izhaja iz vasi Wūjiăo (屋脚). Ta različica koledarja je starejša od primerljivih, ki so predstavljene in klasificirane v Song (2003). Pričujoča študija poglobljeno predstavi značilnosti pisave Daba in konteksta, v katerem je to besedilo nastalo, in se uporablja še dandanes. Članek lahko služi tudi kot filološka osnova za nadaljnje raziskave pisave Daba in s tem povezanih študij.

Ključne besede: pisava Daba; Gemu; vas Wujiao; lunarne lože; interpretacija pisave 


\section{Introduction}

Daba script used to write down calendars is the only written literature of Dabaism discovered so far. Dabaism is the local religion of $\mathrm{Na}$ People living on the border between Yunnan and Sichuan Provinces in South-West China. Dabaism shares the same origin with Dongbaism, another local religion of Naxi People living in Lijiāng (丽江) area, Yunnan Province. Their different designations are due to dialectal differences between $\mathrm{Na}$ and Naxi. Dabaism derives from the local word for their priests, "Daba". Similarly, Dongbaism is derived from the word "Dongba", referred to their priests, in Naxi language. ${ }^{1}$

Dabaism, attested in Héngduàn (横断) Mountains, for a long time has been considered as an eastern branch of Dongbaism without writings (cf. Li, 1984, p. 38; He \& Jiang, 1985, p. 117). ${ }^{2}$ The earliest literature records of Daba script available now is by Zhuang Xueyou in 1940 on a Journal entitled Liáng Yǒu (良友) (Good Friend). However, it was just a bulletin reporting that Moso People have pictograms, without any detail about what kind of pictograms they are (cf. Song, 2003, p. 86). Inspired by that report, Song Zhaolin (宋兆麟) went to Moso area and collected one Daba calendar in 1963 in Yǒngníng (永宁) Township, Nínglàng (宁蒗) County, Yunnan Province. However, Song Zhaolin had not the opportunity to do research in depth until 2000 (cf. Song, 2003, p. 86). Basing on his field work data in 2000 in Lúgū (沪沽) Lake area, four versions of Daba calendars from four villages have been reported by him. Moreover, three among them are presented with a systematic interpretation for each symbol in Song (2003). Some other scholars have also considered the Daba calendar as the bearer of Daba symbols since 1980s. Yang (1994, pp. 32-35) wrote a brief report on this topic based on his first-hand field work data. In the paragraph of the book about a comparative study on Tibetan Buddhism among Tibetan People, Naxi People, and Pumi People, the author has shown a figure with 32 symbols, interpreted by him one-by-one. In the summer of 2010, Zhao Liming conducted a long field work following Song Zhaollin's suggestions. She has collected the latest information on the existing written texts of various ethnic groups living on the border of Yunnan and Sichuan Provinces. Later on, in the National Social Science Fund Project "Interpretation and Rescue of Endangered Scripts and Bibliographies in Southwest China" (10\&ZD123) advised by her, I was in charge of the interpretation of Daba script. From January 2011 to January 2015, I have fulfilled several field work trips to the Daba and Dongba areas. The preliminary data presented in this paper have been collected during my two field work trips in 2011 from Wūjiǎo (屋脚) Village, Wūjiǎo (屋脚) Township, Mùlì (木里) County, Sichuan Province.

\footnotetext{
${ }^{1} \mathrm{Na}$ is now listed as an independent language (ISO 639-3: nru), while Naxi is coded as ISO 639-3: $\mathrm{nxq}$. In China, however, they are considered dialects of the same language: $\mathrm{Na}$ is the eastern branch of Naxi language.

${ }^{2}$ Distinguished from Dabaism, Dongbaism has a relatively mature writing system known as Dongba hieroglyphs (cf. Li et al., 1972).
} 
Wujiao Village has a population of around 300 people, composed of Mongolian and Yi nationalities. The endonym of those Mongolian People living there is [naJhĩ]]. Their language resembles to Naxi language. In other words, they are in fact $\mathrm{Na}$ People, the eastern branch of Naxi People, but not a branch of the Mongolian linguistic milieu. ${ }^{3}$ Dabaism and Tibetan Buddhism coexist in Wujiao Village. There were six Daba priests and seven Lama priests (the Tibetan Buddhism monks) during my field work.

\section{Literature Review}

Yang (1994, pp. 32-35) presents an interpretation of 32 Daba glyphs ${ }^{4}$ including: pronunciation of the glyph in local language transcribed by Chinese characters, the literal meaning of each glyph, and the divination meaning of the glyph. In this interpretation, nine glyphs are related to animals, seven are related to sex, four are related to stars, four are related to human body parts, two represents diseases, other two heterogeneous notions / items (No. 6: wealth/property and No. 25: poisonous food). Four other glyphs are not yet interpreted. The divination meanings are simply auspicious, ominous, or neutral, except for one glyph representing auspicious if there is a battle and ominous if it is a normal day. In his short conclusion, Yang has pointed out some characteristics of these Daba glyphs: 1 ) these glyphs are assigned to the days around one year without apparent links to the dates; 2) the pronunciations of the glyphs are mainly ancient Moso language, which is merely understood by current people; 3 ) the knowledge of these glyphs and the calendars are held only by a few elder Daba priests, not approachable by common people.

Song Zhaolin's interpretation of Daba script is a work based on each calendar. He presented the glyphs used for 28 days in the first month with 1) the pronunciation(s) of the glyph(s) in one grid of the calendar by Chinese characters, 2 ) the meaning(s) of the word(s), 3) the day is auspicious, ominous, or neutral, 4) the suitable activities and not suitable actions on that day. The three versions of Daba calendars interpreted in Song (2003) include two types: each day represented by either one glyph or two glyphs. The calendar with single glyphs for each day contains 28 different glyphs. The calendar with double glyphs for each day is a combination of these 28 glyphs with some other glyphs. The calendar written with the 28 single glyphs is considered the more aboriginal type. Applying the "Liù Shū" theory (六书) ${ }^{5}$ on the analysis of Daba script, Song Zhaolin

\footnotetext{
${ }^{3} \mathrm{Na}$ People have been recognized as Mongolian People during the official census of nationalities in China in 1950s, which has been a mistake. Naxi People, in their turn, have been named according to their endonym [navGit] (He \& Jiang, 1985, p. 2).

${ }^{4}$ In Yang (1994, pp. 32-35), Daba glyphs are defined as "picto-glyph" (túhuà wénzì 图画文字).

5 "Liù Shū" theory (六书) is a traditional philological theoretical framework aimed at the analysis of the composition of Chinese characters proposed by Xǔ Shèn (许慎) (58-147 AD), a scholar from Han Dynasty (206 BC - 220 AD). According to this theory, Chinese characters can be divided into six categories based on the six manners they were created: xiàngxíngzi 象形字 (pictograms), zhǐshìzì 指 事字 (simple indicatives), huìyìì 会意字 (compound indicatives), xíngshēngzì 形声字 (phono-
} 
has concluded that most of the glyphs are pictograms (xiàngxíng 象形) and simple indicatives (zhǐshì 指事). Moreover, he claims that the Daba glyphs are characters ${ }^{6}$ according to three factors: 1 ) they have stable shapes; 2 ) these glyphs can write down the relatively complicate calendar, which has different contents for 360 days per year; 3 ) the glyphs in Daba calendars are widely recognized and used by Daba priests. Compared to Dongba writing, however, Daba script shows to be less mature as a writing system. The author listed three reasons: 1 ) pictograms are much more than simple indicatives; 2 ) variants of glyphs are spotted among different calendars; 3 ) these characters are used only to write down Daba calendars, not applicable to write down other Daba classics.

Yang (1994) and Song (2003) are two important references in the study of Daba script. Being pioneer researches on this topic, they have discovered the existence of Daba script and have provided a general idea of this pictographic writing. However, there is still need to work in-depth on the glyphs. For example, Chinese and $\mathrm{Na}$ have quite different phonemic systems. Therefore, the transcription of the pronunciations of the glyphs in $\mathrm{Na}$ by Chinese characters is not accurate enough as source. Moreover, due to inaccurate transcription, it is difficult to find out the relationship of the glyphs meaning with the daily vocabulary. This could lead to misinterpretation of these glyphs. ${ }^{7}$ Further on, an unclear point in these two reports is the number of Daba characters. Song (2003) seems to count on the Daba calendars themselves, since he has provided scanned copies of Daba calendars. Conversely, the 32 Daba glyphs displayed in Yang (1994, p. 32) could be a combined elicitation from two versions of Daba calendars. In other words, the single glyph set used in Daba calendars contains 28 units. However, the number of the additional glyphs set was not clarified by Song (2003). Instead, Song has stated the total number of the glyphs appearing in double glyph calendars as it results from this sentence: "...it has several more characters, more than 30 pictographs in all" (Song, 2003, p. 90). According to his interpretation of data, the meanings of this additional set of glyphs include "throat", "sun", "moon", "eye", "palm", "throat", and "nose". The words for the two "throats" are different. Nevertheless, that was not explained in the paper.

$\mathrm{Xu}$ (2013) is a preliminary study on the philological issues of Daba script. Three versions of Daba calendars from three different villages have been systematically analyzed. Comparing forms, pronunciations, and meanings of the glyphs, the author established some relevant hermeneutic points: 1) Daba script should be configured as a kind of ancient conventional symbols (Istrin, 1987, p. 77), at the earliest stage of the local

semantic compound characters), jiǎjièzì 假借字 (phonetic loans), and zhuănzhùzì 转注字 (derived characters). Cf. Xu (2001, p. 314) and Boltz (1993, pp. 432-433).

${ }^{6}$ In Song (2003), Daba glyphs are defined as "pictographic characters" (xiàngxíng wénzì 象形文字).

${ }^{7}$ For example, the third symbol in the first calendar sounds as bàokuài (报快) (transcribed into Chinese pinyin) and is interpreted as "the penis of the goat" Song (2003, p. 86). However, according to my knowledge of Na language, the first syllable could be "frog" and the second is "mouth". Therefore, the compound word means the "the mouth of the frog". 
writing; 2) the original Daba script contains 28 symbols representing the lunar mansions in Daba tradition; 3) some loan-symbols are likely to be derived from Tibetan Buddhism.

In order to clarify obscure points in the current available academic publications on Daba script, it is necessary to provide a more accurate description and interpretation of Daba writing, and of its bearer, Daba calendar, as well. In this paper, I will apply a linguistic perspective in order to try to understand the meanings of Daba symbols according to the local language.

\section{Interpretation of Gemu from Wujiao Village}

The specific Daba calendar interpreted in this paper is from Wūjiǎo (屋脚) Village, Wūjiăo (屋脚) Township, Mùlǐ (木里) County, Sichuan Province. The calendar is about $40 \mathrm{~cm}$ in length and $18 \mathrm{~cm}$ in height. It consists of six pages, with the symbols written by calligraphic brush from the left to the right. It is a single symbol type of calendar (as stated by Song (2003)), where each day is written through a (only one) corresponding symbol.

The Daba priest preserving the calendar is called Dawa. Dawa was born in 1929, and passed away in 2012. According to the interview with him, the calendar is entitled [ku-tmvil] "Gemu", literally means "the book of the stars". The first segment "ge" means "star" and the second segment "mu" means "book". It has been handed down from his ancestors. Dawa spent in Wujiao Village all his life.

This Daba calendar was firstly interpreted by me with the cooperation of Daba Awo, the son of Daba Dawa, during my field work in January 2011. Daba Awo is born in 1967. $\mathrm{He}$ is one of the most knowledgeable Daba priests in Wujiao Village. He started to learn Daba culture since he was 10 years old following Daba Dawa. When he was 21 years old, he started to conduct rituals by himself. The recorded data and interpretation have been checked with him again during my field work in July 2011 in Wujiao village.

Having noticed that the glyphs are repeated every 28 units, I have inferred they correspond to the 28 lunar mansions in Daba culture. I numbered the first cycle in the first month from 1 to 28 according to the star groups Daba Awo has divided during the interpretation work. Later on, in order to understand completely the constellation system, I have compared the Daba symbols with Dongba stars documented in academic publications. Since Dongba stars have been equated to Chinese and Western astronomical designations, I had the opportunity to connect these Daba mansions with those 28 lunar mansion systems from other main stream cultures, including Chinese, Tibetan, and Indian. The detailed comparison can be found in Xu (2015). In this paper, I annotate directly the correspondences of the 28 lunar mansions with the Chinese lunar mansions and the western designations for the stars or asterisms, if applicable, in order to provide a more comprehensive scenario of Daba lunar mansions represented by Daba glyphs. 
The interpretation presented below lists: 1) Daba glyph; 2) IPA transcription of the glyph's pronunciation in the Na language; 3 ) Chinese translation of the name of the specific lunar mansion represented by the related symbol; 4) literal meaning of the lunar mansion; 5) the corresponding Chinese lunar mansion or star; ${ }^{8} 6$ ) the Western designation of the lunar mansion or star; 7) IPA transcription of the divination comments of the glyph; ${ }^{9} 8$ ) word-by-word gloss; 9) translation of the whole sentence; 10) my conclusive remarks on the suitable and non-suitable activities on that day.



Figure 1: The First Page of Wujiao Daba Calendar

\subsection{The "Human Being" Constellation}

\begin{tabular}{|c|c|c|}
\hline Script & 28. $\frac{9}{0}$ & 18 \\
\hline $\mathrm{Na}$ & $\mathrm{p}^{\mathrm{h}} æ-\mathrm{mi}-1$ & nitdit-1 \\
\hline Chinese & Pàmǐ (帕米) & Nǐzhì (拟至) \\
\hline Literal Meaning & --- & --- \\
\hline \begin{tabular}{|l|} 
Chinese Lunar Mansion \\
\end{tabular} & \multicolumn{2}{|c|}{ Hégǔ 2 (河鼓二) } \\
\hline Western Designation & \multicolumn{2}{|c|}{ Altair (Aquila) } \\
\hline
\end{tabular}

IPA transcription of the divination comments of the glyphs:
(1) $\mathrm{p}^{\text {h }}$ æt mit mut t ${ }^{h}{ }^{\text {it }}$ zont,
$\mid \varepsilon\rfloor t \epsilon^{\mathrm{h} i t}$
$t^{\mathrm{h}} \varepsilon+\mathrm{t}^{\mathrm{h}} \mathrm{i}$.
the day of Pami funeral
etc.
to discard to go

Translation: (On the days of "Pami" and "Nizhi",) it is not allowed to celebrate funerals. If a funeral is celebrated, someone will die in the following day.

Remarks: The day when "Pami" or "Nizhi" is "on duty" is not good for funerals.

\footnotetext{
${ }^{8} \mathrm{I}$ am providing the Chinese translations, since they are directly derived from field work notes.

${ }^{9}$ The transcriptions record the tones and pronunciations of the words in sentences in order to provide more comprehensive picture of $\mathrm{Na}$ language.
} 


\subsection{The "Horse" Constellation}

\begin{tabular}{||l|c||}
\hline Script & 2. \\
\hline $\mathrm{Na}$ & zwæ \\
\hline Chinese & Mǎ Xīng (马星) \\
\hline Literal Meaning & star of horse \\
\hline Chinese Lunar Mansion & Húguā (瓠瓜) \\
\hline Western Designation & Hugua (Delphinus) \\
\hline
\end{tabular}

IPA transcription of the divination comments of the glyph:

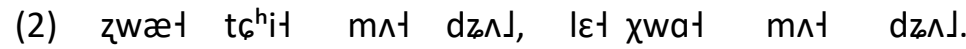 horse to sell not good to buy not good

Translation: (On the day of "Ma Xing",) the exchanges of horses are not auspicious.

Remarks: The day when Hugua is on duty is not good for horses' exchange.

\subsection{The "Frog" Constellation}

\begin{tabular}{|c|c|c|c|c|}
\hline Script & & & & 6. \\
\hline $\mathrm{Na}$ & $p \wedge t k^{h} w \wedge t$ & p $\wedge$ tdzut & dzutkm」 & $\left.p \wedge-k m\rfloor p^{h} m\right\rfloor$ \\
\hline Chinese & $\begin{array}{c}\text { Wāzuǐ Xīng } \\
\text { (蛙嘴星) }\end{array}$ & $\begin{array}{l}\text { Wāniào Xīng } \\
\text { (蛙尿星) }\end{array}$ & $\begin{array}{l}\text { Shuǐ Xīng } \\
\text { (水星) }\end{array}$ & $\begin{array}{l}\text { Báiwā Xīng } \\
\text { (白蛙星) }\end{array}$ \\
\hline Literal Meaning & $\begin{array}{l}\text { the mouth } \\
\text { of frog }\end{array}$ & $\begin{array}{l}\text { the urine } \\
\text { of frog }\end{array}$ & $\begin{array}{l}\text { the star } \\
\text { of water }\end{array}$ & $\begin{array}{l}\text { a white star from the } \\
\text { constellation "frog" }\end{array}$ \\
\hline $\begin{array}{l}\text { Chinese Lunar } \\
\text { Mansion }\end{array}$ & $\begin{array}{l}\text { Shì } \\
\text { (室) }\end{array}$ & $\begin{array}{c}\text { Bì } \\
\text { (壁) }\end{array}$ & $\begin{array}{l}\text { Kuí } \\
\text { (奎) }\end{array}$ & $\begin{array}{l}\text { Lóu } \\
\text { (娄) }\end{array}$ \\
\hline $\begin{array}{l}\text { Western } \\
\text { Designation }\end{array}$ & $\begin{array}{c}\text { Markab and } \\
\text { Scheat }\end{array}$ & $\begin{array}{l}\text { Algenib and } \\
\text { Sirrah }\end{array}$ & Legs & Bond \\
\hline
\end{tabular}

IPA transcription of the divination comments of the glyphs:

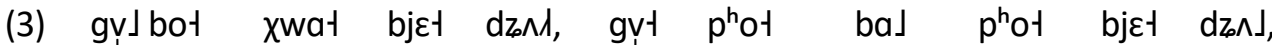
livestock to buy too good crop to sow crop to sow FUT. good

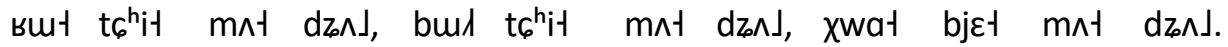
bull to sell not good yak to sell not good to buy FUT. not good

Translation: (On the days of "Wazui Xing", "Waniao Xing", "Shui Xing", and "Baiwa Xing",) the exchanges of livestock are good. It is also auspicious to work in the field. But the exchanges of bulls and yaks are not good.

Remarks: During the days when stars/asterisms from the "Frog" Constellation are on duty, the exchanges of livestock are auspicious, except bulls and yaks. These are good days to sow and to work in the field. 


\subsection{The "Six Stars" Constellation}

\begin{tabular}{|c|c|c|}
\hline Script & $\Delta$ & 8.88 \\
\hline $\mathrm{Na}$ & $q^{h} \imath^{h} 7 t s æ 7 q^{h} \iota^{-1}$ & 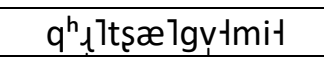 \\
\hline Chinese & $\begin{array}{l}\text { "Kezha" Jiǎo } \\
\text { ("科扎"角) }\end{array}$ & $\begin{array}{l}\text { "Kezha" Shēn } \\
\text { ("科扎"身) }\end{array}$ \\
\hline Literal Meaning & the horn of "Kezha" & The body of "Kezha" \\
\hline Chinese Lunar Mansion & \multicolumn{2}{|c|}{ Mǎo (昂) } \\
\hline Western Designation & \multicolumn{2}{|c|}{ Pleiades } \\
\hline
\end{tabular}

IPA transcription of the divination comments of the glyphs:

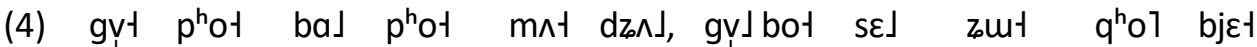
crop to sow crop to sow not good livestock blood to have to kill FUT.

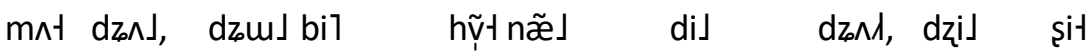
not good mountain area wild animals to chase good money to look for вwat sit bit dzol, ?atbot gyJ bot $q^{\text {hol }}$ bit mountain to look for FUT. good home livestock to kill FUT.

lat mat dzol, t6 $6^{\text {hit }}$ bit lat mat dzol. then not good to sell FUT. then not good

Translation: (On the days of the "Kezha",) it is not good to sow and work in the field. The livestock with blood (mammals) cannot be killed. It is allowed to hunt. All the animals hunted from the mountains are good. To kill the household livestock (bulls, horses, sheep, and pigs) is not good (to other livestock at home). To sell them is not good either.

Remarks: During the days when stars/asterisms from the "Six Stars" Constellation are on duty, it is not allowed to work in the field, either to kill or exchange livestock. They are good days for hunting.

\subsection{The "Red Eye" Constellation}

\begin{tabular}{|l|c||}
\hline Script & 9. \\
\hline Na & njã̃ Jhṽł \\
\hline Chinese & Hóngyăn Xīng (红眼星) \\
\hline Literal Meaning & red eye \\
\hline Chinese Lunar Mansion & Bì (壁) \\
\hline Western Designation & Aldebaran \\
\hline
\end{tabular}


IPA transcription of the divination comments of the glyph:

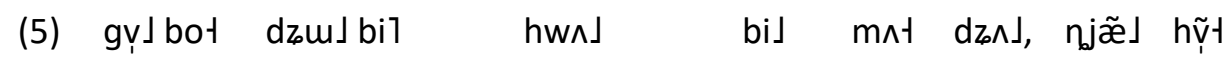
livestock mountain area to shepherd to go not good eye red

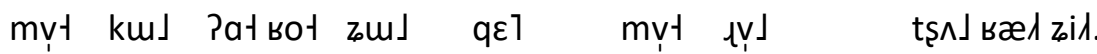
fire star home house to burn fire forest fire pay attention

Translation: On the day of "Hongyan Xing", it is not allowed to bring livestock (bulls, horses, sheep, etc.) into the mountains; (people are not allowed to go into the mountains). On this day, people should pay attention to fire.

Remarks: The day when "Hongyan Xing" is on duty, is not suitable to go into the mountains. It is a day to avoid fire.

\subsection{The "Three Stars" Constellation}

Daba Awo explained this star group as the "sheep" constellation and did not give specific names of each star. The comparison with other Daba calendars and Dongba lunar mansions, from the perspectives of pronunciation and characters' shape, indicates the designation of the constellation as "three stars". Significant evidence is findable in the word pronunciation, since the first syllable in these Daba and Dongba lunar mansions means "three". In Naxi language, the word "three" is [suJ] (Li et al., 1972 , p. 118, No. 1537), while in Na language the word "three" is [sot]. Moreover, the lunar mansions are depicted by three circles in Daba calendar. In Dongba writing, these lunar mansions are composed by three circles with additional symbols indicating the pronunciation of some syllables of the lunar mansions' names.

\begin{tabular}{|c|c|c|c|c|}
\hline Script & $\omega_{10}^{\infty}$ & 11. 8 & ${ }_{12 .} \boldsymbol{\phi}^{\mathbf{\theta}}$ & \\
\hline $\mathrm{Na}$ & solt ${ }^{\mathrm{h}}$ atkot & solt ${ }^{\text {h }}$ atlod & solt ${ }^{\mathrm{h}} \mathrm{atts}^{\mathrm{h}}{ }^{\mathrm{w}} \mathrm{A}$-mit & soJt $t^{h} a t k u-1 p^{h} u-$ \\
\hline Chinese & $\begin{array}{l}\text { Sānxīng Tóu } \\
\text { (三星头) }\end{array}$ & $\begin{array}{c}\text { Sānxīng Shǒu } \\
\text { (三星手) }\end{array}$ & \begin{tabular}{|c|} 
Sānxīng "Chuōmī" \\
(三星"唯咪")
\end{tabular} & $\begin{array}{c}\text { Sānxīng Báixīng } \\
\text { (三星白星) }\end{array}$ \\
\hline \begin{tabular}{|l|} 
Literal \\
Meaning
\end{tabular} & \multicolumn{4}{|c|}{ the stars of "sheep" } \\
\hline $\begin{array}{l}\text { Chinese Lunar } \\
\text { Mansion }\end{array}$ & $\begin{array}{l}\text { Shēn } \\
\text { (参) }\end{array}$ & $\begin{array}{l}\text { Fá } \\
\text { (伐) }\end{array}$ & --- & $\begin{array}{c}\text { Tiānláng Xíng } \\
\text { (天狼星) }\end{array}$ \\
\hline $\begin{array}{l}\text { Western } \\
\text { Designation }\end{array}$ & Orion's Belt & $\begin{array}{c}\text { Orion's } \\
\text { Broadsword }\end{array}$ & --- & Sirius \\
\hline
\end{tabular}

IPA transcription of the divination comments of the glyphs:

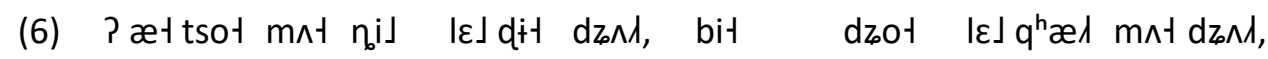
what not COP. to get good outside EXIST. to give not good

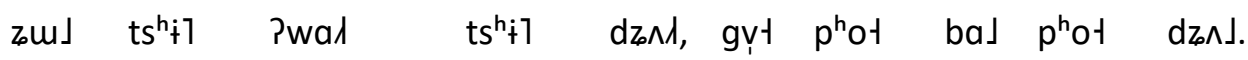
house to build foundation to build good crop to sow crop to sow good 


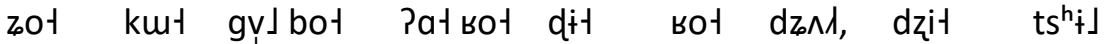

$$
\begin{aligned}
& \text { sheep star livestock home to get back good money to come }
\end{aligned}
$$

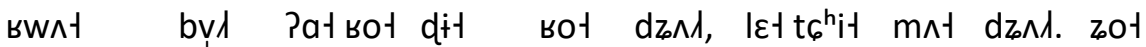

$$
\begin{aligned}
& \text { mountain many home to get back good to sell not good sheep } \\
& \mathrm{t}^{\mathrm{h}} \mathrm{it} \mathrm{m} \wedge \mathrm{d} \mathrm{d} \wedge \mathrm{d} \text {. } \\
& \text { to sell not good }
\end{aligned}
$$

Translation: (On the days of "Sanxing Tou", "Sanxing Shou", "Sanxing Chuomī", and "Sanxing Baixing",) it is good to get things and not good to give away things; it is good to build the houses and to establish the foundations of houses; it is good to sow and to work in the field. On the days of the constellation "sheep", it is good to buy livestock, to achieve big income; it is not good to sell sheep.

Remarks: During the days when the stars/asterisms from the "Three Stars" Constellation are on duty, it is auspicious to take in instead of giving out stuff. They are days suitable to build up houses and to work in the fields. It is not auspicious to sell sheep.

\subsection{The "Pheasant" Constellation}

\begin{tabular}{|l|c||}
\hline Script & 14. \\
\hline $\mathrm{Na}$ & hotkut \\
\hline Chinese & Yějī Xīng (野鸡星) \\
\hline Literal Meaning & star of pheasant \\
\hline Chinese Lunar Mansion & Guǐ (鬼) \\
\hline Western Designation & Beehive Cluster \\
\hline \hline
\end{tabular}

IPA transcription of the divination comments of the glyph:

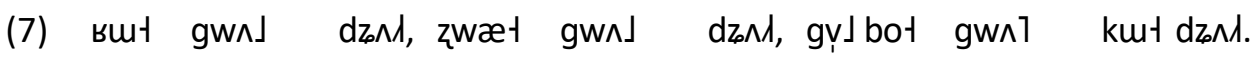
bull to teach good horse to teach good livestock to teach star good

Translation: (On the day of "Yeji Xing",) it is good to teach bulls and horses how to work. It is good to teach livestock that day.

Remarks: The day in which "Yeji Xing" is on duty is suitable to tame livestock. 


\subsection{The "Hawk" Constellation}

\begin{tabular}{|l|c||}
\hline \multirow{2}{*}{ Script } & 15. \\
\hline $\mathrm{Na}$ & k^Jkut \\
\hline Chinese & Yīng Xīng (鹰星) \\
\hline Literal Meaning & star of hawk \\
\hline Chinese Lunar Mansion & Wǔdìuò (五帝座) \\
\hline Western Designation & Denebola \\
\hline
\end{tabular}

IPA transcription of the divination comments of the glyph:

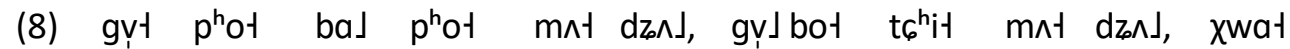
crop to sow crop to sow not good livestock to sell not good to buy

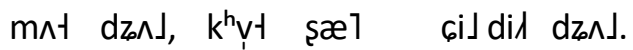
not good dog to pull to fish good

Translation: (On the day of "Ying Xing",) it is not good to sow or to work in the field; it is not good to buy or to sell livestock. Only fishing or hunting is suitable for that day.

Remarks: The day in which "Ying Xing" is on duty, it is suitable to fish and to hunt. It is not allowed to grow crop, to work in the field, or to exchange livestock.

\subsection{The "Pig" Constellation}

\begin{tabular}{|c|c|c|c|}
\hline Script & & & 18. \\
\hline $\mathrm{Na}$ & boJk $k^{h} w A t$ & boJdzut & boJmat \\
\hline Chinese & $\begin{array}{c}\text { Zhūzuǐ Xīng } \\
\text { (猪嘴星) }\end{array}$ & $\begin{array}{c}\text { Zhūniào Xīng } \\
\text { (猪尿星) }\end{array}$ & $\begin{array}{c}\text { Zhūyóu Xīng } \\
\text { (猪油星) }\end{array}$ \\
\hline Literal Meaning & the mouth of pig & the urine of pig & the fat of pig \\
\hline $\begin{array}{l}\text { Chinese Lunar } \\
\text { Mansion }\end{array}$ & $\begin{array}{l}\text { Xuānyuán Shísì } \\
\text { (轩辕十四) }\end{array}$ & $\begin{array}{c}\text { Xuānyuán Shí'èr } \\
\text { (轩辕十二) }\end{array}$ & $\begin{array}{c}\text { Tàiwēiyòuyuán } \\
\text { (太微右垣) }\end{array}$ \\
\hline $\begin{array}{l}\text { Western } \\
\text { Designation }\end{array}$ & Regulus & Algieba & $\begin{array}{l}\text { Two among } \sigma \text { Leo, ı } \\
\text { Leo, } \theta \text { Leo, and } \delta \text { Leo }\end{array}$ \\
\hline
\end{tabular}

IPA transcription of the divination comments of the glyphs:

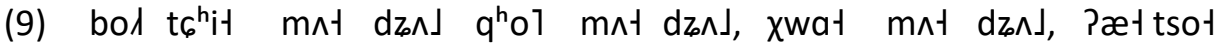
pig to sell not good to kill not good to buy not good what $\mathrm{m} \wedge t$ n.i」 dz^l. not COP. good 
Translation: (On the days of "Zhuzui Xing", "Zhuniao Xing", and "Zhuyou Xing",) it is not good to sell pigs, to kill pigs, or to buy pigs. All the others things are good to be done.

Remarks: During the days when the stars/asterisms from the "Pig" Constellation are on duty, everything is allowed to be done, except to exchange or to kill pigs.

\subsection{The "Mdzo" Constellation}

Daba Awo did not give the explanation for syllable [z广j]. I gloss it as "mdzo" according to the results of comparisons with my field work data from other villages and other studies on Dongba lunar mansions (cf. Xu, 2015, pp. 70-71).

\begin{tabular}{|c|c|c|c|c|c|}
\hline Script & 19. $9 \mathbf{0}$ & & 21. & 22. & 23. I T \\
\hline $\mathrm{Na}$ & $\mathrm{zi}\rfloor \mathrm{zV}{ }^{\prime}$ & $\mathrm{z} \dot{\mathrm{i}}\lrcorner \mathrm{q}^{\mathrm{h}} \mathrm{l}^{-1}$ & $\mathrm{zi}\rfloor \mathrm{hi} \dagger$ & $\mathrm{z} \dot{\mathrm{i}}\lrcorner \mathrm{n} j \mathfrak{\mathfrak { x }}-1$ & $\mathrm{zi}\lrcorner g \mathrm{~g}^{\dagger}$ \\
\hline Chinese & $\begin{array}{l}\text { Piānniú Sì } \\
\text { (犏牛四) }\end{array}$ & $\begin{array}{c}\text { Piānniú Jiǎo } \\
\text { (犏牛角) }\end{array}$ & $\begin{array}{l}\text { Piānniú Ěr } \\
\text { (犏牛耳) }\end{array}$ & $\begin{array}{c}\text { Piānniú Yǎn } \\
\text { (犏牛眼) }\end{array}$ & $\begin{array}{c}\text { Piānniú Zhǎng } \\
\text { (犏牛掌) }\end{array}$ \\
\hline \begin{tabular}{|l|} 
Literal \\
Meaning \\
\end{tabular} & $\begin{array}{c}\text { four sides of } \\
\text { mdzo }\end{array}$ & $\begin{array}{c}\text { the horn of } \\
\text { mdzo }\end{array}$ & $\begin{array}{c}\text { the ear of } \\
\text { mdzo }\end{array}$ & $\begin{array}{c}\text { the eye of } \\
\text { mdzo }\end{array}$ & $\begin{array}{c}\text { the foot of } \\
\text { mdzo }\end{array}$ \\
\hline \begin{tabular}{|l} 
Chinese Lunar \\
Mansion
\end{tabular} & \multicolumn{5}{|c|}{ The area between Jiǎo (角) and Jī (箕) } \\
\hline $\begin{array}{l}\text { Western } \\
\text { Designation }\end{array}$ & \multicolumn{5}{|c|}{ The area between the Horn mansion (Spica) to Winnowing Basket } \\
\hline
\end{tabular}

IPA transcription of the divination comments of the glyphs:

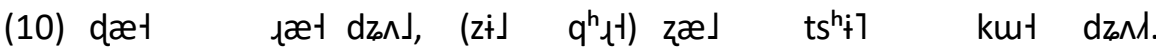
foundation flat good mdzo horn column to build star good

Translation: (On the days of "Pianniu Si", " Pianniu Jiao", " Pianniu Er", " Pianniu Yan", and "Pianniu Zhang"), it is good to make the foundation of houses flat. It is good to erect columns on the day of "Pianniu Jiao". (Nothing is forbidden during these days.)

Remarks: During the days when the stars/asterisms from the "Mdzo" Constellation are on duty, it is allowed to build the foundation of the houses. During the day in which "Piānniú Jiǎo" is on duty, it is good to erect the columns. Nothing is forbidden.

\subsection{The Unknown Constellation (Hǔzuǐ Xīng (虎嘴星) and Ròushí Xīng (肉食星))}

They are two local 'original' stars. It has not yet been possible to find reliable parallels in Dongba culture and other major cultures. 


\begin{tabular}{|c|c|c|}
\hline Script & & \\
\hline $\mathrm{Na}$ & lathỹ $\mid k^{h} w \wedge t$ & s^」dzi」dvit \\
\hline Chinese & Hǔzuǐ Xīng (虎嘴星) & Ròushí Xīng (肉食星) \\
\hline Literal Meaning & $\begin{array}{l}\text { the star of } \\
\text { tiger's mouth }\end{array}$ & $\begin{array}{l}\text { the star of } \\
\text { carnivore }\end{array}$ \\
\hline Chinese Lunar Mansion & \multicolumn{2}{|c|}{--} \\
\hline Western Designation & \multicolumn{2}{|c|}{--} \\
\hline
\end{tabular}

IPA transcription of the divination comments of the glyphs:

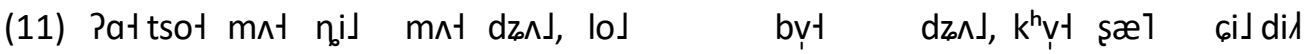
what not COP. not good incantation to chant good dog to pull to fish

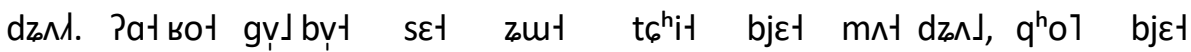
good other livestock blood to have to sell FUT. not good to kill FUT.

$m \wedge t$ dzı」, $\chi w a t$ bjet $m \wedge t$ dzı」. not good to buy too not good

Translation: (On the days of "Huzui Xing" and "Roushi Xing",) nothing is good to be done except chanting incantations in order to expel ghosts, and pulling dogs (to hunt) and fishing. It is not good to sell livestock, to buy livestock, or to kill livestock.

Remarks: During the days when "Huzui Xing" and "Roushi Xing" are on duty, it is allowed to chant spells to expel ghosts and to hunt. Nothing else is allowed, especially exchanging and/or killing livestock.

\subsection{The Unknown Constellation (Tóu Xīng (头星) and Wěi Xīng (尾星))}

\begin{tabular}{|c|c|c|}
\hline Script & 26. & 27. \\
\hline $\mathrm{Na}$ & swæł ${ }^{h} w \wedge t$ & $m æ J q^{h} w \wedge-1$ \\
\hline Chinese & Tóu Xīng (头星) & Wěi Xīng (尾星) \\
\hline Literal Meaning & the head star & the tail star \\
\hline Chinese Lunar Mansion & Jī (箕) & Dǒu (斗) \\
\hline Western Designation & Winnowing Basket & Dipper \\
\hline
\end{tabular}

IPA transcription of the divination comments of the glyphs:

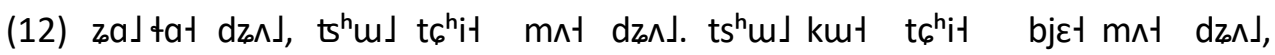
others good goat to sell not good goat star to sell go not good

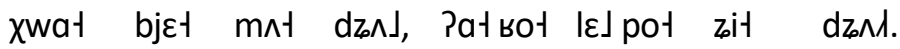
to buy to go not good home to bring back good

Translation: (On the day of "Tou Xing" and "Wei Xing",) there is nothing bad, except to sell goats or to buy goats. It is good to bring back home stuff. 
Remarks: During the days when "Tou Xing" and "Wei Xing" are on duty, it is good to bring stuff into the house, not good to exchange goats. Nothing else is forbidden.

\section{Conclusion}

The present study aims to be a primary source for philological documentation and research on Daba script, with an accurate transcription and introduction of field word data. After having reviewed the available academic studies on Daba script, I pointed out the need of a detailed report describing Daba script.

In the third section of this work, I have presented the interpretation of Daba script from an old Daba calendar, Gemu, from Wujiao Village. This is a single-symbol Daba calendar, indeed the most original kind of calendar according to the classification established by Song $(2003$, p. 86).

Daba calendar is used by the priests in order to select auspicious days for rituals. Therefore, it can be classified into hemerology among different types of calendars. During the field work in which I have tried to decipher these glyphs, I noticed that Daba priests recite by heart the 28 lunar mansions names in a certain order, rather than reading them one-by-one. In other words, they depend more on their memory of the star system than on the written texts. The designations are relatively fixed according to the related positions among these 28 glyphs. This explains why the visual representation of the same lunar mansion could be different among the villages.

This is the first report introducing all-embracing information on Daba glyphs and Daba calendar (in its different versions). It provides an exact transcription of the glyphs' pronunciations and religious prescriptions in the local language, with Chinese and English glosses and translations. Moreover, it lists all the divination prescriptions related to the 28 lunar mansions in Daba context.

Daba culture has developed a specific and original methodology in choosing stars/asterisms in order to calculate the dates. Interpreting this traditional system, I have annotated the corresponding Chinese lunar mansions and their Western designations as well. This can help in identifying Daba script and the lunar mansions recorded by these ideograms in their whole cultural background, considering also their relationships with lunar mansions/stars in other (related and unrelated) cultures. 


\section{References}

Boltz, W. (1993). Shuo wen chieh tzu [說文解字]. In M. Loewe (Ed.), Early Chinese Texts: A Bibliographical Guide (pp. 429-442). Early China Special Monograph Series No. 2. Berkeley: Society for the Study of Early China, and the Institute of East Asian Studies, University of California.

Istrin, V. (1987). Vozniknoveniye i razvitiye pis'ma [The Emergence and Development of Writing]. (S. Zuo [左少兴], Trans.). Beijing [北京]: Beijing Daxue Chubanshe [北京大学出 版社].

He, J. [和即仁], \& Jiang, Z. [姜竹仪] (1985). Nàxīyǔ Jiănzhì [纳西语简志] [A Brief Description of the Naxi Language]. Beijing [北京]: Minzu Chubanshe [民族出版社].

Li, L. [李霖灿], Zhang, K. [张琨], \& He, C. [和才] (1972). A Dictionary of Mo-So Hieroglyphics. Taipei [台北]: Wenshizhe Chubanshe [文史哲出版社].

Li, L. [李霖灿] (1984). Mósuō Yánjiū Lùnwénjí [麼些研究论文集] [Collection of Papers on Moso Studies]. Taipei: National Palace Museum.

Song, Z. [宋兆麟] (2003). Mósuōrén de Xiàngxíng Wénzì 摩梭人的象形文字 [Hieroglyphic Writing of Moso People]. Southeast Culture, (4), 86-93.

Xu, D. [许多多] (2013). Dábā Lìshū Jiědú jí Fúhào Xìngzhì Chūtàn [达巴历书解读及符号性质 初探] [An Interpretation of Ephemeris of Dabaism and Discussion of the Symbols' Nature]. Yuyanxue Yanjiu [语言学研究] [Linguistic Studies], 13(1), 40-51.

Xu, D. [许多多] (2015). A Comparison of the Twenty-Eight Lunar Mansions between Dabaism and Dongbaism. Archaeoastronomy and Ancient Technologies, 3(2), 61-81.

Xu, S. [许慎][Han Dynasty] (2001). Shuō Wén Jiě Zì [说文解字] [An Etymological Dictionary Explaining Graphemes and Analyzing Characters]. Nanjing [南京]: Jiangsu Guji Chubanshe [江苏古籍出版社].

Yang, X. [杨学政] (1994). Zàngzú, Nàxīzú, Pǔmǐzú de Zàngchuán Fójiào: Dìyù Mínzú Zōngjiào Yánjiū [藏族, 纳西族, 普米族的藏传佛教: 地域民族宗教研究] [The Tibetan Buddhism of Tibetan People, Naxi People, and Pumi People: A Study of Regional Ethnic Religion]. Kunming [昆明]: Yunnan Renmin Chubanshe [云南人民出版社]. 